\title{
GPRC5C wt Allele
}

National Cancer Institute

\section{Source}

National Cancer Institute. GPRC5C wt Allele. NCI Thesaurus. Code C51461.

Human GPRC5C wild-type allele is located within $17 q 25$ and is approximately $20 \mathrm{~kb}$ in length. This allele, which encodes $\mathrm{G}$-protein coupled receptor family $\mathrm{C}$ group 5 member $\mathrm{C}$ protein, is involved in a function that has not been identified to date, however; it may play a role in the mediation of retinoic acid effects on $\mathrm{G}$ protein signal transduction. 